\title{
Administrative Law in the Sphere of Public Policy upon Restoration of Independence of Latvia and Lithuania
}

\author{
Janis Načisčionis \\ Turiba University \\ Zemgale Suburb, LV-1058 Riga, Latvia
}

Algimantas Urmonas

Mykolas Rpmeris University

Ateities g. 20, LT-08303 Vilnius, Lithuania

cross'ref $^{\text {http://dx.doi.org/10.5755/j01.ppaa.20.1.27712 }}$

\begin{abstract}
The authors of the article explore the multi-functionality of administrative law. Administrative legislation should take into account social realities, recognize the usefulness of social order (when assessing the need for legislative changes or their stability) and transfer them to the level of justice (in terms of the adequacy of legal regulation). After the restoration of independence, administrative law in Latvia and Lithuania had to undergo a transformation of values, abandon the imposed Soviet ideological standards and master new standards of democracies. This strengthened social and legal values, enshrined and protected in the Constitutions of both countries and after accession to the EU, in accordance with the provisions of public administration, allowed by the Treaty on the Functioning of the European Union.The article notes that the formation of legislative policy and the creation of legislation usually based on the discretion of the culture of politicians. The authors of the article draw attention to the synergistic knowledge of social reality and the use of this knowledge when building administrative and legal regulation to the level of macro-social regulation.
\end{abstract} values

Keywords: administrative law, social reality, public policy, public administration, social

Raktažodžiai: administracinè teisè, socialinè tikrové, viešoji politika, viešasis administravimas, socialinès vertybès

\section{Introduction}

The problem concerning knowledge and assessment of administrative law is associated with certain social and legal realities. It is an evaluative interdisciplinary and legally cross-sectoral social category. In this respect, the content of social reality is associated with social values. Administrative law also guards and protects social values, which are generalized and formed as legal values in the constitutions of Latvia and Lithuania.

The relationship between administrative law and social reality has yet to be researched extensively. Broader studies of social reality have been carried out in sociology (Valantiejus, 2007, Bagdanavičius, 2005 and others). Legal scholars have also studied social reality in some nonfragmentary aspects: Šlapkauskas $(2006,2009)$ - sociology of law, Urmonas (2006) - administrative law, Dobrynina (2009) criminology. Jarašiūnas (2006, 2009), Levichev (2015) and others have studied legal reality as certain phenomena of social reality.Administrative law as an object of practical activity of society is a manifestation of social reality, i.e., legal reality. At the same time, it refers to a value system that helps to create and change social reality. On the other hand, it is pertinent to understand how the values of social reality affect administrative law.

Dwelling deeper into social reality, one can understand those features of social and legal values that influenced the formation of administrative law. Consequently, administrative law can be 
assessed in terms of values of the relevant social environment in which its ideas, norms, principles and judicial practice were formed. Hence, this retrospective evaluative process of administrative law is associated with certain historical processes. A retrospective study of social reality shows the dynamic side of administrative law: the factors influencing social change, social and legal values "transferable" through public policy to administrative law. From the point of view of a deeper knowledge of administrative law, the object of this study is the processes of democratization of public policy in Latvia and Lithuania, which influenced the formation of modern administrative law.

Law facilitates goal-oriented activities of people, but does not replace people's own creativity. In this sense, the purpose and objectives of this article are to identify general trends in the formation of modern administrative law in Latvia and Lithuania, which reject the implementation of the values common between the occupying state and countries restoring their independence.

The main revolutionary transformation of modern administrative law in Latvia and Lithuania is associated with the beginning of the National Awakening and democratic movements in 1987-1989 and with the periods of restoration of independence since 1990. The main socio-political and social values and legal ideas were formed during this period, which laid the future framework for administrative law of the independent states. The condemnation of the Molotov-Ribbentrop Pact of 23 August 1939 between Germany and the Soviet Union began in the Baltic and was significant in this context. In accordance with the Molotov-Ribbentrop Pact, Latvia and Lithuania were transferred to the sphere of influence of the Soviet Union. This paved the way for the Soviet Union in June 1940 to occupy and annex Latvia and Lithuania. The values of the totalitarian ideology of the state were imposed on the Baltic States and enshrined in foreign administrative law. For example, a textbook on Soviet administrative law published in 1940 stated: "The party exposed vile sabotage designs and ensured the triumph of Marxist - Leninist ideas in law science and in particular in the field of socialist administrative law. [...] The complete defeat of the counter-revolutionary gangs put an end to the damaging underestimation of the role of Soviet administrative law."

For the purposes and objectives of the article, information was gathered on the basis of a qualitative analysis of documents (e.g., legal acts, strategic programs and implementation plans at various levels, international conventions, declarations, policy guidelines for certain areas of public administration); the authors' experience gained through scientific and practical work in law enforcement institutions and analysis of scientific literature, system analysis, scientific experience as well as practical work in law enforcement systems ${ }^{1}$.

\footnotetext{
${ }^{1}$ In particular, A. Urmonas has 50 years of scientific and practical experience. From 1970 to 1983 , he conducted comparative research in the field of offenders and law-abiding persons, compiled annual summaries of statistical reviews of offences at the Forensic Science Research Institute.
}

Between 1972 and 1978 he conducted interdisciplinary dissertation (doctoral) research on the topic "Criminological problems of studying the personality of a criminal, i.e., a thief", assessed various dissertation research works conducted in Latvia, Belarus and Russia, and also participated in scientific conferences. From 1984 to 1990 he taught administrative law at Vilnius Faculty of Minsk Higher School of the Ministry of Internal Affairs (now Mykolas Romeris University). From 1989-1990, he worked on the draft of the Law on Police.

He supervised 15 dissertations at Mykolas Romeris University, many of which relate to the field of interdisciplinary administrative law. He also taught administrative law at Vytautas Magnus University and Kaunas University of Technology. He has written over 80 different scientific publications.

From 1993-2001, he headed the Strategic Development Department of the Ministry of the Interior of Lithuania and participated in the development of the most important draft laws in the field of law enforcement (Law on the Financial Crime Investigation Service of the Republic of Lithuania; Law on the Security Department, Law on the Fundamentals of Police Activities of the Republic of Lithuania, Law of the Republic of Lithuania Republic on the Control of Weapons and Ammunition, Laws on Amendments to the Code of Administrative Offences of the Republic of Lithuania 1993-1998, etc.) 
The article emphasizes that the main narrative of the revival of values, changes from the values of the occupation regime, is human orientation. In the Soviet system, the values of the state and society led by the Communist Party were at the forefront while human values were ranked last on the scale of values. The value-oriented changes that took place in Latvia and Lithuania were implemented through the creation of a democratic legal system (the Constitution, institutional system, theoretical doctrines of administrative law, laws etc.). This revolutionary and evolutionary transformation took place in the public sector of Latvia and Lithuania with the active participation of specialists in various fields, taking into account the modern and predictable social legal reality. A socially constructed legal reality can be explained as a continuous, dynamic process, constantly updated by people acting on the basis of their interpretations and knowledge of this reality. In this regard, some subjectivity of the legislative process is also taken into account.

\section{Administrative law and social reality ${ }^{2}$}

Similarly to other branches of national law, administrative law is subject to social changes that transform its instrumental normative and legal function in the society. After the restoration of independence, it abandoned the functions of guarding and protecting Soviet values, the ideologized legal norms imposed on the occupied Latvia and Lithuania, characteristic of totalitarian regimes, where the interests of the state have priority. In such states, a person and his/her needs and interests are pushed to the social margin and only the needs and interests of those who belong to the totalitarian elite predominate.

With the prevalence of democracy, administrative law actualizes those human legal values that are enshrined in the Constitutions of Latvia and Lithuania, harmonizes them with the Treaty on the Functioning of the European Union and the guidelines adopted by public administration.

The enhancement of social reality naturally raises the question of compatibility of the relationship between administrative law and this reality. Social reality can be viewed from a multilayered perspective. It includes politics, economics, law, culture, society etc. All these segments, affected by the feedback from real processes of social reality, create a further change in social reality. Administrative law, enriched with visions and missions of social change, can use its instrumental powers to construct various expressions of the model of social reality.

Administrative law $^{3}$ can be actualised with the help of various objects of social reality: culture, economics, politics, ideology, management, environment, society and other forms of behaviour regulated by law. Such administrative and legal interactions are characterized not only by bidirectional, but also multidirectional impact of information. This interaction of administrative law is characterized not only by the ambiguity of information effects, but also by the directional nature of information effects. For example, administrative law as a manifestation of culture influences cultural phenomena, interacting directly with culture and through feedback. At the same time, culture as a multi-layered social phenomenon influences administrative law, helps identify its strengths and weaknesses and affects its qualitative characteristics. Administrative law should be a consistent mediator in the complex process of the informational impact of the social objects under analysis, take into account numerous aspects of the social process and strengthen its main regulatory functions.

Therefore, in order to understand and evaluate the social function of administrative law, to objectively assess the impact of administrative doctrine and the effectiveness of influence on social

\footnotetext{
${ }^{2}$ [Reality, actuality [lot. realis - real - material]: everything that objectively exists and is reflected in the historical process of cognition as an object of practical activity of society.] https://www.zodynas.lt/tarptautinis-zodziu-zodynas/R/realybe

${ }^{3}$ Administrative law, from the point of view of a social phenomenon, develops on the basis of the division of a subject into an object. This means that the products of public legal consciousness must be embodied in objects regulated by administrative law. If this is not so, no unity of this subject-object is to be found, which means that in these relations no essence, i.e., the manifestation of the subject, is present
} 
sciences, legal systems and the social environment in general, to identify the factors that determine changes in administrative law, it is necessary to understand the essence of social and legal interaction.

Social and legal interaction is a category of social cognition. Applying a systemic approach towards it can reveal:

- the connection between various social and legal entities,

- direct and indirect interactions,

- the course of logically related processes,

- certain correlations among common communication objects,

- changes in the state of various subjects and objects,

- social characteristics of the influence of the emergence of new social objects.

The authors believe that the object of social and legal interaction is a certain behaviour of the subjects of social and legal activity, social and legal processes. It is known that both the behaviour of the subjects of this activity and the ongoing social processes are significant from an administrative and legal point of view. Information about social interactions is required only to the extent that it can be used to achieve the desired administrative and legal corrections of this interaction. Social interaction, being a source of information for social management of a particular object, is used to achieve and facilitate legal goals in the field of public administration and create conditions for the implementation of administrative law functions.

Similarly to other social sciences, administrative law, is theoretically and empirically related to human relations in society. It instrumentally establishes positive standards of human behaviour and determines which standards of human behaviour deviate from the norm, are undesirable and therefore are to be assessed from the point of view of administrative liability. Thus, administrative law is at the epicentre of social phenomena as a factor in the organization of the society that determines and controls the macro-structural and micro-structural foundations of human behaviour.

Therefore, it is rational to view administrative law as a social phenomenon interacting with other social phenomena in accordance with the criteria for perceiving social reality, to study the macro-objective relations of the whole and the part. It is well known that social and legal cognition measures the relationship of human thinking to social reality from subjective perception to the establishment of objective truth. The extent to which this can be identified is undoubtedly determined by the methodology and research methods. In other words, there should be a close connection between the science of administrative law and the practitioners of administrative law: legislators, subjects of public administration, courts. This means that social changes will be properly recognized and assessed and adequate legal instruments will be selected in laws to achieve social legal transformations. Thus, knowledge of social change must be assessed from an interdisciplinary perspective and the pursuit of social legal change must be based on synergistic solutions.

According to Valantiejus, "attention should be paid to the doubling of the subject and object, researcher and reality. The object of the social sciences is social reality. The word "social" refers to the nature of the interaction. And the term "interaction" contributes to the understanding that, strictly speaking, there is no real subject and object. There is only an analytical subject and an analytical object. Thus, primarily because of the social relations between subject and object, all analytical categories are social constructions, including subject and object, individual and society, action and structure" (Valantiejus, 2006, 62).

Value assessment of the measurement of the social environment "[...] in some objects and phenomena we see more reality than in nature, that they are more significant for us than natural objects in themselves, and allow us to talk about social reality as a kind of world of cultural objects. This is a world in which a person, his efforts and desires are involved." (Karosas, 2000, 37). Thus, social reality can be viewed as an objectively existing reality on the one hand and as a reality perceived by human knowledge on the other. "The fact is that the image of the world depends on the observer: different characteristics, senses and states of movement of observers determine their different perceptions of reality" (Laitmanas, 2007, 80). 
Thus, the state, structure and dynamics of the branch of administrative law are "placed" between objectively existing phenomena of social reality and knowledge of social reality, perceived by human knowledge. The fact that in social "reality" a person exists in the context of order, direction and stability creates a stable environment for his/her behaviour.

However, creation takes place not because people create notions themselves, but because people "adopt" the world in which others already live" (Berger, Luckmann, 1999, 164): this is an important goal for all branches of law, including administrative law, as they define legal constructs of the legal order. A deeper knowledge of social reality increases the ability to control the development of administrative law, to have a positive impact on the interaction between administrative law and other social phenomena.

The value instruments of administrative law show that, on the one hand, through the mechanism of public administration, especially through its retroactive force, it affects social control in various areas of social reality: economics, politics, culture, social communication, physical and social existence of a person, thus forming a legitimate system of values. In the environment, on the other hand, the aforementioned areas of social reality affect administrative law through feedback, i.e., information on the results of the regulation of administrative law are provided.

This can be used to assess the strengths and weaknesses, threats or newly perceived opportunities for administrative legal regulation. Thus, the variability or stability of administrative law reveals the advisability of using information, its value in interaction with social factors for the formation of public policy and improvement of legislation. However, the formation of law-making policy and the creation of legislation is usually based on the discretion of political culture, since their goals, efforts and desires are directly related to the political ideology of the party, which is a value related to the behaviour of various parties and groups of influence. These values compete with the political, economic, cultural and other social interests of other parties and groups in society. These interests or factors are repeatedly "filtered" through the consciousness of people, e.g., during elections, assessing the activities of parliamentarians in power and in the opposition, the mass media and so on; and thus these factors should be assessed in the specific context of their interactions. Therefore, it is difficult to directly link economic, political and other social factors with the impact on legislation in terms of assessing the objectivity of social cognition. The idea of the formation of the branch of administrative law is based not only on the epistemological, but also on the cultural aspect. On the other hand, politicians with political interests ignore the legal ideology: scientific legal ideas, general legal values, science-based concepts, research programs, legal principles etc. As a result, when assessing the corresponding social and legal reality, it is not enough to look at the future development of administrative law in a systematic, holistic ("concentrated") way, without taking into account specific life situations.

Many parliamentarians suffer from a non-systematic, fragmented approach to law-making processes that are directly "taken" from instant solutions to certain legal situations. Since administrative law and social change are social phenomena, it is necessary to look at the definitions of these phenomena from a broader, constructive point of view of social cognition. Both the creation of administrative law and the process of social change are "represented" by a person in the interest of his activities. Thus, administrative law and social change are socially constructed by people. In their interaction, it is important to understand the value of these phenomena. It should be emphasized that the object of social cognition is not an abstract personality, but a person, i.e., a member of society, through which s/he becomes a subject of activity, realizing certain social values: “... only those objects that are of public or social interest become historically significant. Consequently, as part of the historical connection with history as a whole, that is, with society, the result, the main object of historical research is not a person, separate from the society in general, but a person, i.e., a social being, and only to the extent that he contributes towards the realization of social values" (Риккерт, In Karosas, 2000, 35).

Thus, in order to identify and form administrative law as a macro-social phenomenon, it is advisable to follow the ideas of social construction. Berger P., Luckman T. distinguish three stages 
of project (schematic) construction of social reality, which can be applied both to the ideas of creating administrative law and understanding the values of social changes (Berger, Luckman, 1995, 13). The theoretical methodological process of constructing social reality is realized through interconnected mechanisms of internalization, externalization and objectification.

Through internalization, people adopt and assimilate examples of the experience of social behaviour, objectified culture and, consequently, legal experience gained from experienced public administration. Internalization helps a person to understand by reason, to try to get to know better the objective processes of the existing society, to interpret them, to create a subjectively real and meaningful world. During internalization, there is also a different assimilation of one or the other stereotype of legal culture, legal customs, norms, principles, public administration and the activities of legal institutions that have been practised in society for a long time or are being practised at the moment. Internalization processes are expressed through the space of direct experience in linguistic, textual, graphic, audio and video forms, forms of direct and indirect communication.

Through externalization, using the adopted and assimilated experience, a new objective world is created by changing or implementing an "intervention" on the influencing environment of social reality, and at the same time, a new social reality is formed. A person is able to choose, decide, recreate, and nuance the influence of his needs on social reality. For this creativity, two types of knowledge are used: the world already known in society or now known, and "what can become known in the future." Cognition of the future of social reality "programs" the channels through which the objective world is created during externalization (Berger, Luckmann, 1999, 89). In terms of cognizing social reality, the individual constantly externalizes himself ${ }^{4}$ : s/he knows social reality in subjective terms (through himself/herself) and internalizes it through objective values (which interact with the environment) (Berger, Luckmann, 1999, 133).

The impact of externalization is associated with the expectation of new knowledge in the future and can be seen in the development of concepts of administrative law, projects, social programs, strategic documents, scientific hypotheses and the formation of theoretical and practical models. The essence of the process of objectification lies in the fact that the products of subjective thinking are transferred to an objectified social space, giving these products of thinking certain forms and methods of material life. This transformation of the subjective product into an objectified world occurs through the creative formation of externalization. Methods of constructing internalization, externalization and objectification as social realities are carried out through the adoption and creation of social meanings based on values. This value basis is important for the existence of administrative law, the stability of its values and its improvement.

The following significant points can be distinguished in the implementation of the values of social cognition in administrative law:

1) As a branch of law, administrative law is a phenomenon in the field of public administration of social life, which, in accordance with the legal value standards of the Constitutions of the Republics of Latvia and Lithuania, establishes desirable, forbidden or dispositively permissible forms and methods of human behaviour. Thanks to predetermined provisions of administrative law, people (as subjects of law) participate in public administration relations in legally significant forms and methods of behaviour. This act (action or inaction) of subjects of law implements legally significant values in the field of public administration. The values are realized in several stages.

First, through the mechanism of legal regulation, the processes of adopting legislation and bylaws are built on the basis of epistemological and cultural knowledge. A variety of social and legal information is used for these processes. The points of resistance and the limits of the choice of values are established by the Constitutions of the Republics of Latvia and Lithuania as well as the Treaty on the Functioning of the European Union signed by both countries. The issues of overstepping these limits are considered in the Constitutional Courts of Latvia and Lithuania and the Court of the

\footnotetext{
${ }^{4}$ Internalization [Latin - internus]: accepting the views, norms, values of a social group, considering it as one's own https://www.zodynas.lt/tarptautinis-zodziu-zodynas/I/internalizacija
} 
European Union. This means that the issues of epistemological and cultural-social cognition in the normative legislation should be resolved without violating national and European legislation. The scope of discretion of the subjects of law making on the adoption of legal acts is limited, but the objectification $^{5}$ of law is a complex process, therefore "the objectivity of the fusion of knowledge with values is problematic by the fact that value is always a definite correlation between the subject and the object"(Karosas, 2000, 40).

Secondly, it can be stated that, in addition to the Constitution, such factors of the macro-level of legal objectification as the national culture, humanistic ideas and the external environment of the Latvian and Lithuanian states, associated with colourful social reality, are of great importance for the formation of basic legal ideas, their perception and transformation into administrative law; both by participating in the activities of the United Nations, the European Union, NATO organizations and by reacting to the actions of other countries hostile to Latvia and Lithuania.

All of the above factors objectively affect not only the normative reality of administrative law, but also the principles of law as well as the case law of the courts. Thus, a system of administrative law, which must correspond to objective reality, is formed.

National and global culture $\leftarrow \rightarrow$ historical and humanistic ideas $\leftarrow \rightarrow$ legal ideas $\leftarrow \rightarrow$ legal doctrine $\leftarrow \rightarrow$ a sketch of a specific draft laws (programs) $\leftarrow \rightarrow$ draft of a specific law.

The implementation of administrative-legal regulation will be especially related to the abovementioned regulatory mechanism, in which the law making of administrative-legal norms and their application in public administration relations, the application of legal principles and case law are of particular importance. Fragmented administrative and legal regulation will depend on the activities of lawyers and legal bodies of state administration in the implementation of legal norms.

The question may arise why this regulation is fragmented. There are several assumptions in the assessment of legislation and public administration which allow us to reasonably assume that the nature of administrative and legal regulation is fragmented.

First, legislation and other legal acts usually take place in an imaginary social reality. For example, the reading and analysis of explanatory notes to legal acts is based on the discretion of the initiators of the draft laws (authorized representatives of institutions, individuals or citizens) and drafters. Of course, the understanding of their essence is focused on cognition, but unfortunately, not on scientific knowledge obtained by applying research methods, analysing information, formulating conclusions and proposals.

The knowledge of subjects regarding social reality of law making is often insufficient. They are usually built on the basis of their own perceptions, knowledge of others, as well as inductive and deductive thinking. It is an indicator of the quality of legislation, which is still often based on empirical, everyday thinking and especially on the "compliance" of legislation to the interests of public policy (Urmonas, 2019, 100-117). A distinctive feature of such a "mandatory" legislative activity is that it is limited to certain narrow marginal frameworks for achieving political interests through administrative regulation.

Such a subjective structure of legislation in the environment of social reality collides with functioning political, economic, socio-psychological and other social factors. They cause social conflict situations, creating dysfunctions of legal relations with social reality. Thus, a gap appears between the legislative construct and social reality. Politicians, or legislators, and other drafters of legal acts again take new legislative action, supplementing or introducing a new formulation of administrative regulation. Politicians reintroduce certain political, economic, social, psychological and other social ideas into the legislative product. Such a rhythm of purely political legislation is comparable to the "work of a perpetual machine", the idea of a perpetual machine, which is fundamentally incomplete, unviable, questionable. i.e., constantly unresolved.

\footnotetext{
${ }^{5}$ The objectification of administrative law is a process of a social phenomenon, when the subjective products of thinking, ideas acquire independently objective material life, i.e., social forms of legal expression. This is the process of social conditioning of law, its reification.
} 
Second, scientific knowledge based on research methods more deeply reflects the objective social reality. According to Hegel, "a method is a weapon that stands on the side of the subject as a means by which he correlates with the object of his knowledge" (Hegel, In Gintalas, 2011, 989). Therefore, it is necessary to talk about legislation in public space in the social systemic and basic categories, emphasizing the synergy of legal and social regulation. Administrative and legal regulation by itself cannot resolve the problems established in various social programs, including the program of each government. For example, the Law on the Control of Alcohol of the Republic of Lithuania was adopted on May 26, 1995. It provides for measures to reduce overall alcohol consumption, alcohol abuse, reduce damage to health and the economy, establish a state monopoly on the production and trade of alcoholic beverages and a state monopoly on the production, sale and import, and accordingly formulates the legal framework for all operators of production, sale and other circulation of alcoholic products.

In order to achieve similar goals, each new subsequent government of Latvia and Lithuania, ministries and other departments must adopt a number of action plans which provide for measures to apply anti-alcohol legislation. Legal measures are constantly opposed to overcoming the social phenomenon of alcoholism. Despite the legal order achieved during a certain period, a certain legal practice is formed, but this social phenomenon keeps transforming and sets new tasks for society. It seems that the social reality of such flourishing alcoholism is of a Sisyphean nature. It is like a contagious disease that is overcome over time and re-emerges as a result of a favourable environment. These examples show that administrative and legal regulation is more limited in addressing social issues and reaches certain temporal and spatial indicators of the rule of law.

The synergistic construction of the relationship between legal and social factors is more strategic, covers the vast boundaries of knowledge ${ }^{6}$ of social reality and is a new product of the synergy of knowledge of the objects of social regulation. Knowledge of the social nature of reality also expands the possible limits of administrative and legal regulation. Synergistic disclosure of knowledge about social reality and the use of this knowledge brings administrative and legal regulation closer to macro social regulation and at the same time raises administrative law to the level of construction of a macro social phenomenon.

According to the synergistic concept ${ }^{7}$, administrative law at the macro level can be defined as follows: macro administrative law is the application of the synergy of knowledge revealed as a result of the study of objective social reality, the establishment and assessment of legally significant standards of human behaviour. It manifests itself in the areas of public administration, instrumental regulation, and the establishment of positive human behaviour in the society. Macro administrative regulation protects the society from the negative consequences of human behaviour. In this case, legal principles and legal norms are used, administrative and legal means are applied. Also, to combine the positive results of regulation with objective needs, other social, economic and managerial means of regulating human behaviour are used that correspond to the goals of administrative regulation.

\section{Administrative law, social reality and social change}

Analysing the role of administrative law in social reality, we understand that at the level of the correlation between the subject and the object of establishing administrative-legal regulation, it is based on certain knowledge of social reality: imaginary, perceived and objectively possible. New social changes can be explained by identifying fundamental interactions between natural and social factors.

Administrative law, performing its regulatory functions, acts as a subject of influence on the state, structure and dynamics of social objects and causes their changes. There is no doubt that the

\footnotetext{
${ }^{6}$ Synergy of knowledge is the result of the processes of interaction of expressive and non-expressive knowledge that affect the activities of a person and organization and create new knowledge. In Katinienè, 2018, 27

${ }^{7}$ Combination of legal and other social knowledge
} 
action of administrative law (subject-object) occurs through human legal relations. Here, anti-alcohol laws, imposing prohibitions in time and space, restrict the excessive consumption of alcohol by certain individuals. Conversely, the overuse of alcohol by many people has created a legal need to curb such a massive destructive social phenomenon by imposing legal prohibitions and liability for violations of legal requirements. Thus, the assessed social reality causes the need to change administrative law. Thus, there is a social interaction between administrative law and other social factors. Administrative law studies the effectiveness of its legal regulation based on the results of social changes, i.e., changes that take place.
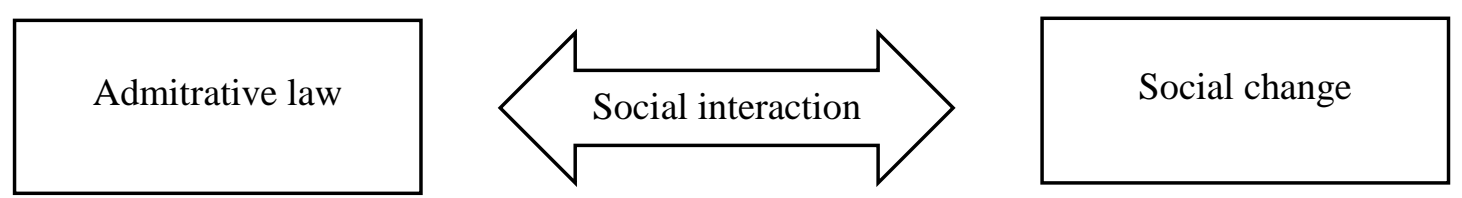

\section{Fig. 1. Interaction between administrative law and social change Source: Authors.}

This analysis shows that it is necessary to understand the essence of social changes and their mutual social interaction with administrative and legal regulation in order to define their concepts. The category of social change is the most widely researched in sociology and management. Depending on the paradigm ${ }^{8}$ of a particular study, social changes are associated with the transition of a social object from one state to another, with changes in the stage of socio-economic development, with a significant variety of social organization, with changes in its institutions and social structure, with changes in established models of social behaviour, with the renewal of institutional forms and their increase and so on. In practice, the interpretation of such changes is usually associated with a more difficult task, i.e., an attempt to determine the causes of the changes or the factors (factors) that led to the effect (the change that occurred). The essence of this goal is to show why such a change happened in one way and not in another (The Great Dictionary of Sociological (COLLINS), (1999, 246). On the other hand, it is important not only to find out what will change and how we need to act, but also explain why it is necessary and what will happen if no change will occur. These ideas can be applied, for example, to the socio-legal analysis of alcoholism, where alcohol use causes various forms of social isolation and marginality and on the other hand, the social organization of society adopts anti-alcohol laws and uses other social means to achieve social order.

Alcoholism

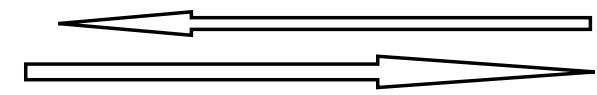

Social organisation of the society as values of certain individuals

Fig. 2. Macro social Interaction: Alcohol consumption contributes to social isolation and social organization of the society has an influence

Source: Authors.

Thus, social change in the most general sense can be defined as any change in the characteristics (including administrative law) of the observed social object. Such changes, as evidenced by the evolution of world society, occur in an evolutionary and revolutionary way. These types of social changes are significant from the administrative and legal point of view, since administrative law "absorbs" the objective needs of a person, society and state through the national culture and through general and legal globalization in recent decades, legal ideas and doctrines. As the legislative practice of the Saeima and Seimas shows, legal systems are being unified. The

\footnotetext{
8 The set of theoretical and methodological assumptions on which a particular study is based. See: https://www.tv3.lt/zodynas/tarptautiniai-zodziai/P/paradigma.
} 
membership of Latvia and Lithuania in the UN, the European Union, etc. is also significant in this context. The development of the use of the official language and in particular the English language of these organizations also contributes to the development of a global culture. These factors affect the reception (adoption) of the norms of administrative law of the EU countries into national legislation. After the accession of Latvia and Lithuania to the EU, various harmonization projects have been implemented.

As far as revolutionary and evolutionary changes in administrative law are concerned, it is necessary to note the first decade of the restoration of the Latvian and Lithuanian states, when more revolutionary changes in administrative law took place along with the other branches of law. How should revolutionary changes in administrative law be understood? Since administrative law is also viewed at the macro level, it is a manifestation of ongoing social phenomena, but at the same time, a change in administrative law is also a social change. This means that we can investigate revolutionary or evolutionary changes in administrative law based on the methodological foundations of social change. So why do social changes take place, and what are their causes? In particular, it is crucial to correctly understand the categories of social reality and social change. The driving force behind social change lies in the sphere of social reality. Valantiejus' remark "Social structure as a metaphor for order" (Valantiejus, 2006/2, 48) is quite accurate.

It is not surprising that this observation is very close to law in general and to administrative law in particular, since as a scientific tool, it seeks a certain structured order in areas of public administration, the values of which stem from the Constitution.

Naturally, after the restoration of independence, the political, economic and other social factors that influenced the striving for independence led to a faster denial and reorganization of the value standards, i.e., the transformation of the "State, society, people" imposed by the occupying state into a democratic social and legal value of "Individual, society, state".

This rapid transformation was largely revolutionary in nature as social change transformed the basic value of social objects ${ }^{9}$. This methodological position was important for Latvia and Lithuania after the restoration of independence, especially during the first decade. The laws adopted during the Soviet era in many cases contradicted the social values of people, society and the democratic states of Latvia and Lithuania from the point of view of the practice of these values. Therefore, the ongoing revolutionary breakthrough in the meaning and actualization of values required new legal regulation: human rights and freedoms, restrictions on power, citizens' participation in governing their country, private property, economy, religion, social justice, citizenship and other issues.

Revolutionary changes in administrative law were inevitable. Empowered by the nation, the parliaments of Latvia and Lithuania responded to this conflict of values in a significant political and legal way. It is gratifying that the Law on the Restoration of the Independent State of Lithuania as of March 11, 1990 and the Declaration on the Restoration of the Independence of the Republic of Latvia of May 4, 1990 politically and legally secured three interrelated values at the legal level (Par Latvijas Republikas neatkarības atjaunošanu, 1990, No. 20). This is the legal continuity of independent states, the cleansing of the consequences of the ideology imposed by the occupying power, overcoming the painful consequences of the multifaceted moral experience and the beginning of a return to the values of European law. At the same time, administrative law learned a lesson from state justice about the possibilities for changing values and their development closer to democratic standards of legal regulation, i.e., a tolerant orientation towards a person, his/her rights and freedoms, democratization of public life, striving for the predominance of the right to identity.

The revolutionary and evolutionary legislation of the restored Seimas based on these values, which consolidated the statehood of Lithuania, neutralized and eliminated the consequences of the occupying power, was important for the development of the country's administrative law. This

\footnotetext{
${ }^{9}$ Точно так же, когда было обнаружено ядро атома, стало ясно, что это произошло во время деления. [Likewise, when the nucleus of an atom was discovered, it became clear that it happened during fission.]
} 
strategic direction was creatively implemented by other government bodies through the adoption of by-laws. It should be noted that under difficult circumstances of the deployment of a foreign army in Lithuania, bold regulations were adopted affirming its sovereignty. The Soviet authorities made political, economic and legal efforts, including the use of military force, to prevent the establishment of the independence of a restored Lithuanian state. With the support of the nation and the recognition of the independence by democratic states, the Lithuanian state demonstrated its political and legal strength by adopting the necessary legal acts and implementing institutional transformations.

The democratic norms of social and state life in interwar Latvia and Lithuania as well as the legal systems of Western European countries have become a valuable example of emerging national administrative law in a general sense. This, in an evaluative, comparative sense, with the help of laws and institutional restructuring of the power structures of Latvia and Lithuania, helped to reject everything that was associated with the false, unnecessary, destructive control function of the ideology of the occupying state over the political, cultural, social identity of the nation and, consequently, over its right.

The ideas of the Popular Front of Latvia ${ }^{10}$ and the Reform Movement of Lithuania (Sajūdis) ${ }^{11}$ in 1988-1990 had a huge value potential for the administrative law of both countries. The positive aspirations of the Popular Front of Latvia were hindered by the International Front of the Working People of the Latvian SSR (Interfront). It was founded by the Russian-speaking members of the reactionary wing of the Latvian communist party (LCP) on January 7, 1989 to counter the Popular Front of Latvia, founded on October 8, 1988. It used the infrastructure of the LCP and the Soviet Army - published a newspaper "Unity" (Vienotība) and created its own radio station "Sodruzhestvo" (Fellowship) from representatives of foreign radio stations. Among its founders and leaders were Igor Lopatin Anatoly Alekseev and Tatyana Zhdanok. In the summer of 1989, its representatives participated in the creation of the United Workers' Front of the USSR.

During the barricades, the leadership of the Interfront gathered about 10,000 participants at the stadium on Kr. Baron on January 15. The political statement of the Latvian Committee for the Salvation of Society stated that it rejected the declaration of 4th May 1990 adopted within the framework of the "Latvian People's Assembly", and that Soviet Latvia should remain a part of the restored USSR. The defenders of the barricades awaited the arrival of participants of the Interfront rally at the centre of Riga, but this did not happen although Interfront leaflets were scattered from the helicopters of the Soviet army.

During the August coup, the Supreme Council of the Republic of Latvia suspended the activities of the Interfront on 24th August 1991 on charges of attempted coup d'état and terminated its activities on 10th September ${ }^{12}$. In the political environment of Lithuania, several alternative extreme political trends appeared. On the right, the Lithuanian Liberty League (LLL), radical at that time by Soviet standards, with the demands of Lithuania's immediate independence and on the left, the transforming Communist Party of Lithuania which was against the independence of Lithuania: communists led by M. Burokevičius on the so-called platform of the Communist party of the Soviet Union (CPSU) ${ }^{13}$. Both Sajūdis and the Lithuanian Communist Party (LKP) had to reconcile with the aspirations for independence and accelerating results of change in Lithuania with the situation in the Soviet Union and the possibilities of "reform" in Lithuania. The strategy and tactics of achieving

10 Tautas atmodas kustība Latvijā.[Latvian national awakening Retrieved 21.07.2020. from https://lv.wikipedia.org/wiki/Tautas_atmodas_kust\%C4\%ABba_Latvij\%C4\%81

${ }^{11}$ Lietuvos Persitvarkymo Sajūdis in Lithuanian.

12 Internacionālā $\quad$ darbaliaužu $\quad$ fronte. $\quad$ Retrieved $\quad$ 21.07.2020. from https://lv.wikipedia.org/wiki/Internacion\%C4\%811\%C4\%81_Darba\%C4\%BCau\%C5\%BEu fronte

${ }^{13}$ On 22 December 1989, at the XX Congress the Communist Party of the Lithuanian SSR, Lithuania was the first republic of the Soviet Union at that time, to separate from the CPSU. 
independence depended on the configuration of various political, economic and social conflicts. The communists, led by M. Burokevičius on the platform of the $\mathrm{CPSU}^{14}$, responded to a situation favourable to Lithuania's aspirations for independence, called on Moscow to introduce direct presidential (Moscow) rule in Lithuania, following the example of Nagorno-Karabakh ${ }^{15}$.

Under the influence of Sajūdis, the people of Lithuania looked to the future in all spheres of their activity, forming values, the foundations of which lay in the ideas of the future law making of an independent democratic Lithuania. Sufficiently realistic political and legal ideas were important in terms of socio-political changes and legal interactions at the time as well as for the formation of envisaged law enforcement structures.

In this case, it is worth mentioning the Law on Police, which is so important from an administrative and legal point of view and which had its basis in the envisaged Police Academy of Lithuania. At that time, the activities of the militia were regulated by the Resolution of the USSR Council of Ministers of 1973 "On the further improvement of legal regulation of the activities of the Soviet militia", which comprised the" Regulations on the Soviet militia".

1989 was characterized by the restoration of pre-war Lithuanian parties, social movements, public and professional organizations. It should be noted that the date of February16 was restored as the National Day of Independent Lithuania, the celebration of which had previously been prohibited for many years. Many professional organizations broke away from similarly named organizations in the USSR. The Lithuanian Society of Lawyers was restored. Finally, on December 20, 1989, during the XX Congress, the LKP broke away from the CPSU. The development of the aforementioned Law on Police was being carried in an atmosphere of national liberation from the occupation regime.

The idea to develop a draft Law on Police of the Lithuanian SSR occurred in 1989 to Professor, Head of the Department of Special Legal Disciplines, Y. Bluvstein of the then Vilnius Faculty of Minsk Higher Institution of the Ministry of Internal Affairs of the USSR, Head of the institution A. Preykshe and his Deputy for Academic Affairs, A. Pumputis. The development of the concept stopped for some time due to the lack of information necessary to develop a new concept corresponding to the ongoing social and political changes. Professor J. Bluvsteinas requested A. Urmonas, a lecturer of the department of special legal disciplines of the faculty, to draft the concept. The initial basic provisions of the concept were presented to the leadership of the faculty. The concept included provisions relevant to the ongoing social changes. The following ideas were proposed: to depoliticize the activities of the police, to be guided by the Constitution of the Lithuanian SSR, other laws and by-laws of the Lithuanian SSR, decisions of local state bodies. In addition, it was stated that the management of police issues falls within the competence of the Soviet republic. In order to prevent the so-called separatism, which was regularly discussed in the Soviet mass media, it was proposed that the police of the Lithuanian SSR would establish and develop professional relations with the relevant institutions of the USSR republics, state and public organizations and foreign countries as well as international organizations. Such were its humble beginnings. The then Minister of Internal Affairs of the Lithuanian SSR (after the restoration of independence and the Republic of Lithuania) Misiukonis became interested in this position of the faculty. The lecturer was requested by the ministerial committee to further develop the concept and simultaneously draft the text of the Law on Police. The ministerial committee divided the work. V. Junokas, A. Tekorius and A. Urmonas became

\footnotetext{
${ }^{14}$ In 1988-1990 the Molotov-Ribbentrop Pact and its consequences, i.e.,occupation and annexation, were talked about more and more in Lithuania and the wish of the Lithuanian nation to live in an independent state became more and more obvious. At that time, forces emerged that opposed the independence of Lithuania, carrying out the policy of the USSR authorities. At the end of 1989, when the Lithuanian communist party (LKP) separated from the CPSU, some participants in the LKP congress, with the approval of the leaders of the Central Committee of the CPSU, announced their withdrawal from the LKP and created the LKP / KPSS organization] In По делу 13 января (I). Организаторы переворота. Bernardinai.lt,. Интернет-газета, 8 января 2013 г.

15 The autonomous region of Azerbaijan Nagorno-Karabakh aspired to become an autonomous republic of NagornoKarabakh. Azerbaijan did not agree; as a result, Moscow introduced a special military rule in Nagorno-Karabakh
} 
members of the "junior committee", which continued working on the law. The senior committee of the ministry met periodically to discuss the provisions of the draft articles prepared by the "junior committee".

The "junior committee" analysed the peculiarities of the activities of the Lithuanian militia (1918-1923) and the Lithuanian police (the militia was officially renamed the police on January 1, 1924). The pre-war documents on the activities of the militia and the police were analysed, i.e., the Law on Militia of May 14, 1920, the Statute of the State Security Department of 1935, the set of Circulars and the Instruction for Police Officers. The experience of the police professional activity in certain areas of law enforcement was also studied. There was also interest in the organizational structure of the police in other European countries. When preparing the draft law on police, the "junior committee" also relied on the provisions of management theory to form the logical structure of the draft law.

During the preparation of the draft, heated discussions took place not only in the committees of the Ministry of Internal Affairs, but also in political and legal circles. The "junior committee" proposed to repeat the path of the pre-war Lithuanian police. The initially reformed militia of the country had to operate in new social and political conditions. Later, after achieving certain qualitative goals of activity, it would evolve into a police force. The politicians thought otherwise stating that the "pro-Soviet" militia should be immediately transformed into a police force. The opinions of the lawyers also differed politically. For example, even before the promulgation of the Draft Law on police, the Commission of the Scientific and Practical Conference of the Lithuanian Society of Lawyers on October 27 presented its findings on the draft Law on the Police of the Lithuanian SSR. Unfortunately, the members of the committees of the Ministry of Internal Affairs were not invited to the conference to explain their conceptual provisions.

There were often discussions in the press about what kind of police the country needs. The opinion was formed that the promulgation of the Draft Law, undoubtedly, would make it possible to quickly orient and reorganize the activities of the militia in a way that is acceptable to the society of the Republic. It was believed that it was necessary to create an independent national militia, financed from the budget of the republic, whose relations with the militias of other republics would be regulated on a parity basis. The law on police should guarantee, not restrict the rights of citizens. Of course, these are the right words, but they did not reflect the truth about how and under what conditions the country lived at that time.

In the published draft Law on Police, Article 4 stated that "the militia of the Lithuanian SSR consists of the self-government and the republican militia" (Lietuvos TSR milicijos istatymas. Projektas, 1990). Importantly, the issue of an over-centralized structure was not even mentioned. Meanwhile, the draft clarified the essence of the concept of militia activity "on the basis of paramilitary discipline" (Article 37, part 3 of the draft). The main emphasis is that "a police officer in statutory relations must fulfil the duties provided for in this law." (citatos nuoroda??) This formulation was necessary at the time, since it was the only military force legally representing the republic in the process of transformation. It is known that police officers with state insignia and attributes of Lithuania caused confusion among high-ranking police officers of other republics, and the Soviet military were dissatisfied with the national cockade during conflict situations, announcing on the radio "to catch those with horses", i.e. intercept those with the state signs of Lithuania (Misiukonis, 2018, 222).

The assertion that "it is necessary to create an independent national militia, financed from the republican budget, whose relations with the militias of other republics should be regulated on a parity basis" is an example of partly excessive criticism. Indeed, Article 6 of the Draft stated that "the police of the Lithuanian SSR establishes and develops professional relations with the relevant state and public institutions of the republics of the USSR and foreign countries as well as with international organizations" (Lietuvos TSR milicijos isstatymas. Projektas, 1990).

When explaining which laws are revolutionary or evolutionary, it should be understood that the orientation towards new legal values is most expressed in a revolutionary spirit. Meanwhile, their 
further implementation in practice requires evolutionary efforts, and this was achieved with the help of law enforcement procedures. A systematic unity of laws and regulations was found. The courts and the jurisprudence did a great job in this respect.

Thus, during its development, the provisions of the Draft law on Police also changed in accordance with the needs of public policy and after the restoration of independence in accordance with the value orientations of the democratic republic.

Historians Laurinavičius and Sirutavičius note that behind the evolutionary revival of national consciousness after the period of Soviet repressions, "the national consciousness of some Soviet Lithuanians was like [that of] the heroes in the drama Mažvydas". The heroes of the drama, in the words of the playwright Justinas Marcinkevicius, called upon to listen attentively to the constantly spoken word Lithuania, using the syllables Lie - tu- va (Li thu ania). (...) Slow and consistent educational work was by no means meaningless, but a fundamentally decisive factor in the restoration of the state "(Laurinavičius, Sirutavičius, 2008, 30).

The choice of revolutionary or evolutionary changes in administrative law is also determined by social and legal reality. After the restoration of independent Lithuania, a number of laws adopted during the period of the occupation regime entered into force provided they did not contradict the value provisions formulated in Article 3 of the Law "On the Provisional Basic Law of the Republic of Lithuania". This directive testified that the laws and other legal acts that had been in force in Lithuania until then and which did not contradict the Provisional Basic Law of the Republic of Lithuania continued to operate in the Republic of Lithuania. The directive followed directly from the provision of Article 4 of the Law "On the Restoration of the Constitution of Lithuania of May 12, 1938", according to which value changes could be perceived, believing that, on the one hand, the effect of the country's laws adopted before the occupation could not be restored. On the other hand, under circumstances of transformation of values into reality, laws adopted until 1990 in the so-called Soviet period may be in effect for a transitional period until they were replaced by new ones.

Among these laws were those that regulated administrative and legal relations. In each case, the Seimas extended their validity period although they were supplemented by new legal provisions. The very name of the law governing this process indicated a certain value of the provision: "The laws in force on the territory of the Republic of Lithuania, adopted before March 11, 1990, Law on provisional extension." It should be noted that this was not a decline in values. The most important legal provisions concerning the occupation's ideological, institutional and other legacy were replaced by new democratic values. It should also be noted that the value orientations of administrative law under the influence of the provisions of the Provisional Basic Law changed the interpretation of the text (literal) concepts of administrative law and destroyed the legal jurisdiction of the USSR in the territory of Lithuania. Human rights and freedoms were particularly clearly guarded and protected, which represented a different set of values than previously assumed, allowing to measure not only the state, but also its legal system, general and legal culture and wider acceptance of civil society. Such a perception constituted an orientation towards the rule of law. For example, among the tasks for administrative offenses, the Code of Administrative Offenses of the Republic of Lithuania refused to protect the public order of the USSR, socialist property and other provisions of Soviet ideological content.

Thus, this code showed a new value direction focused on a democratic social system and its attributes, i.e., essential, inalienable features of a democratic nature. On the other hand, it should be noted that the provisions of the Code of Administrative Offenses refer to the concept of public interest, and the revolutionary value of the ideological cleansing of the law does not impede the safeguard and protection of various areas of public interest. In addition, the Code of Administrative Offenses adapted to the recently created and further changing social reality. In addition, in Lithuania, after Lithuania's accession to the EU, provisions of the norms governed by the legal acts of the European Union appeared. Among them were directives such as the European Parliament and the Council directives on genetically modified organisms, the Council Regulation on the measures necessary to protect the euro against counterfeiting; electrical and electronic waste; protection of 
intellectual property rights, etc. In general, the period before accession to the EU was characterized by the harmonization of legal acts ${ }^{16}$ of the Republic of Lithuania with European legal acts. The harmonization of legal acts was carried out in accordance with the "Guidelines for the harmonization of national legislation with the legislation of the European Union" (1999). A comparatively similar yet different situation existed in the Republic of Latvia with regard to administrative liability. In accordance with Article 6 of the Declaration on the Restoration of Independence of the Republic of Latvia "During the transitional period the Constitution of the Latvian SSR and other laws of the Latvian SSR in force at the time when the declaration was made may be applicable as long as they do not contradict articles 1, 2, 3 and 6 of the Constitution of Latvia." (Par Latvijas Republikas neatkaribas atjaunošanu. 1990). Thus, the Code of Administrative Offenses of Latvia, adopted by the Supreme Soviet of the Latvian SSR on December 7, 1984, became part of the legal regulation of administrative liability in independent Latvia. For a long time, law practitioners and academics have been working on changes in order to improve the legal regulation of administrative liability. The main emphasis was on putting an end to the Soviet, in fact, legal regulation, which is unusual for an independent state and to move on to a modern Western legal regulation.

On July 1, 2020, a long-prepared reform of administrative liability came into force: the Latvian Code of Administrative Offenses was replaced by the Law on Administrative Liability (Administratīvās atbildības likums, 2018) (which defines the procedure for penalties for administrative violations) and, according to amendments, more than 100 sectoral laws (determining the composition and penalties for violations). Consequently, the previously codified area of administrative responsibility has been decentralized.

According to the study by A. Savicka, "one of the aspects of the modern change in values is a change in the motivation for work and an assessment of the importance of material well-being: in the conditions of long-term economic growth and increased social security, work is less and less considered as a source of income by people, it is important that work should be interesting and meaningful. At the same time, of course, the importance of material well-being diminishes" (Savicka, 2016, 227).

\section{Conclusions}

1. The main transformation of modern administrative law in Latvia and Lithuania is associated with the beginning of the National Awakening and democratic movements in 1987-1989 and with the restoration of independence in 1990. At that time, the main social and political values and legal ideas were formed which determined the future outlines of the administrative law of independent states. The condemnation of the Molotov-Ribbentrop Pact of 23 August 1939 between Germany and the Soviet Union began in the Baltics and played a significant role. Naturally, after the restoration of independence, political, economic and other social factors that influenced the desire for independence led to a more rapid rejection and transformation of the value standards imposed by the occupying state.

2. The establishment of administrative and legal regulation is based on certain knowledge of a person of social reality: imaginary, perceived and objectively possible. It is necessary to understand the essence of social and legal interaction in order to cognize and evaluate the social function of administrative law informatively, to objectively evaluate the doctrine of administrative law and the effectiveness of activities subject to it, to identify the factors that determine the change in administrative law.

3. A retrospective study of social reality reveals changes in administrative law: when social changes are influenced by socio-legal values, they are "transferred" to administrative law through

\footnotetext{
16 The situation with the transposition and implementation of EU legislation in Lithuania was constantly analyzed and assessed. Since it is the subject of separate consideration, the authors restrict themselves to a note on the influence of this factor on the subject of administrative law and social changes. Transposition and implementation of EU legislation into national legislation is an ongoing process.
} 
public policy. The notion of social change should be viewed from an interdisciplinary perspective and the pursuit of social legal change should be based on synergistic solutions. A deeper knowledge of social reality increases the ability to control the development of the branch of administrative law, to have a positive impact on the interaction between administrative law and other social phenomena.

\section{References}

1. Administratīvās atbildības likums. Latvijas Vēstnesis. 14.11.2018.Nr. 225.

2. Bagdanavičius, J. (2011). Socialinès sferos sociologija: teorinis metodologinis aspektas. Vilnius: Lietuvos edukologijos universiteto leidykla.

3. Berger, P. L. Luckmann Th. (1999). Socialinis tikrovès konstravimas. Žinojimo sociologijos traktatas. Vilnius: Pradai.

4. Dobrynina, M. (2009). Kriminologinio žinojimo konstravimas: valdžios vaidmuo. Teisès problemos, Vol.4 (66), p. 109-125

5. Hegel, G. W. F. Science of Logic. London, 2004, p. 827. In Gintalas, A. Metodologijos ir metodo samprata. Socialinių mokslų studijos : mokslo darbai = Social sciences studies : research papers / Mykolo Romerio universitetas. Vilnius: Mykolo Romerio universitetas. 2011, Nr. 3(3).

6. Jarašiūnas, E. (2006). Jurisprudencinè konstitucija. Jurisprudencija. Vilnius: Mykolo Romerio universiteto Leidybos centras. Nr. 12 (90), p. 24-33.

7. Jarašiūnas, E. (2009). Oficialios konstitucinès doktrinos koregavimo problemos. Jurisprudencija. Nr. 1 (115), p. 39-70.

8. Valantiejus, A. Socialinès struktūros samprata. Sociologija. Mintis ir veiksmas 2006/2.

9. Karosas, J. (2000). Socialinis pažinimas kaip vertybių teorija (W. Windelbandas, H. Rickertas). Problemos. 57.

10. Katinienè, A. (2018). Organizacijos darbuotojų žinių sinergijos vertinimas. Daktaro disertacija. Vilnius: Technika.

11. Laitmanas, M. (2007). Iš chaoso $i$ harmoniją. Vilnius: VšI „Kabalos studijų centras“. http://www.laitman.1t/chaosas/skyrius09.php

12. Laurinavičius, Č., Sirutavičius, V. (2008). Sajūdis: nuo „persitvarkymo" iki kovo 11-osios. In Lietuvos istorija, t. XII, I d., Vilnius: Baltos lankos.

13. Levičev, V. Holistinis požiūris ị teisès tyrimus. Vilnius: Vilniaus universiteto leidykla. Teisé, 2015 m., T. 95 , p. 111-122.

14. Lietuvos TSR milicijos įstatymas. Projektas. Liaudies sargyboje, 1990 m. sausio 15 -22 d., Nr.3 (796).

15. Misiukonis, M. Lemtingi metai. VRM istoriniuose ivvykiuose. Vilnius: Mintis, 2018.

16. Par Latvijas Republikas neatkarības atjaunošanu. Latvijas Republikas Augstākās Padomes un Valdības Ziņotājs.17.05.1990.Nr.20.

17. Savicka, A. (2016). Postmaterialiuju vertybiu raida netikrumo salygomis. In Lietuvos visuomenès vertybiu kaita per dvidešimt nepriklausomybès metų. Monografija. Vilnius: Vilniaus universiteto leidykla.

18. Šlapkauskas, V. (2006). Teisinès sistemos disfunkcija - silpnos socialinès politikos požymis. Socialinis darbas. t. 5 , Nr. 1. p. 21-29.

19. Šlapkauskas, V. (2009). Teisès vaidmens silpnėjimo komercializuotoje visuomenèje. Jurisprudencija. Nr. 4 (118), p. 265-284

20. Urmonas, A. (2006). Administracinè teisė socialinių pokyčių erdvèje. Jurisprudencija. 2006, 5(83); 37-47.

21. Urmonas, A. (2019). Teisėkūros sąveikų su viešaja politika ypatumai Lietuvoje. Viešoji politika ir administravimas = Public policy and administration. Kaunas: Kauno Technologijos universitetas, Mykolo Romerio universitetas. 2019, t. 18, Nr. 1, p. 100-117.

22. Valantiejus, A. Socialinès struktūros samprata. Sociologija. Mintis ir veiksmas 2006/2.

23. Valantiejus, A. Sociologijos istorija: teorinés idejos, problemos ir sqvokos / I d. Sociologijos filosofija. Vilniaus universitetas / Socialinių tyrimų institutas. - Vilnius : Vilniaus universiteto leidykla, 2007.

24. Риккерт, Г. Науки о природе и науки о культуре. Санкт - Петербург,1911,с. 68. In Karosas, J. Socialinis pažinimas kaip vertybių teorija (Windelbandas, W. Rickertas H.). Problemos. 2000. 57, p. 35.

25. Бергер. П., Лукман. Т. Социальное конструирование реальности. Трактат по социологии знания. М.: Издательство «Медум», 1995. - С. 13.

26. Большой толковый социологический (COLLINS) словарь. Том 2 (П-Я): Пер. с англ.- Вече, АCT, 1999 , с. 246.

27. Методические указания по приведению национальных правовых актов в соответствие с законодательством Европейского Союза были утверждены Генеральным директором Департамента европейского права при Правительстве Литовской Республики в 1999 году. 24 декабря по приказу № 19.

28. http://www.etd.lt/lit/nacionalines-teises-aktu-derinimo-su-europos-sajungos-teise-metodiniai-nurodymai...direktoriaus-1999-m-gruodzio-/48 
Jānis Načisčionis, Algimantas Urmonas

\section{Administracinė teisè, socialinė tikrovè, viešoji politika ir socialiniai pokyčiai}

\section{Anotacija}

Administracinè teisè yra socialinès tikrovès atspindys, paveiktas viešosios politikos ir viešųu interesų sąveikos. Svarbus šios sąveikos katalizatorius yra socialiniai pokyčiai. Administracinès teisès kaita yra nuolat veikiama dviejų skirtingų veiksnių: naudingumo ir teisingumo. Viešoji politika remiasi naudingumo, o administracinè teisè - teisingumo paradigma. Šiu paradigmų tarpusavio suderinamumas buvo ir yra svarbiausias socialinių pokyčių valdymo objektas. Straipsnyje šie suderinamumo klausimai nagrinejjami remiantis pateikiamais atskirų teisès aktų teisèkūros vyksmo pavyzdžiais. Socialinių pokyčių yra veikiami visi dinaminiai socialiniai objektai. Administracinè teisė atsiduria socialinių reiškinių kaitos epicentre, kaip visuomenès organizavimosi veiksnys, nustatantis ir kontroliuojantis žmonių elgesio makrostruktūrinius ir mikrostruktūrinius pagrindus. Straipsnio autoriai atskleidžia administracinès teisès daugiafunkciškumą. Administracinè teisėkūra turi atsižvelgti ị socialinę tikrovę, akceptuoti socialinès tvarkos naudingumo požymius (vertinant teisès aktų kaitos ar stabilumo poreikius) ir juos perkelti ị teisingumo lygmenị (teisinio reguliavimo tinkamumo požiūriu). Administracinè teisè, atgavus nepriklausomybę Latvijoje ir Lietuvoje turèjo pereiti vertybini virsmą, atsisakyti primestų sovietinių ideologizuotų standartų ir įsisavinti naujus demokratinių valstybių standartus. Juos issisavinant buvo konkretizuojamos abiejų šalių Konstitucijose saugomos ir ginamos socialinès teisinès vertybės ir įstojus į ES, derintasi su Sutarties dèl Europos Sajungos veikimo toleruojamomis viešojo administravimo nuostatomis. Straipsnyje pažymima, kad teisėkūros politikos formavimas ir teisès aktų kūryba dažniau remiasi politikų kultūros diskrecija. Autoriai atkreipia dėmesị i sinerginị socialinės tikrovès pažinimą ir to pažinimo panaudojimą, konstruojant administracinį teisinį reguliavimą iki makrosocialinio reguliavimo lygmens.

Jānis Načisčionis - mokslų doktaras, profesorius, Teisès fakulteto dekanas, Turibos Universitete Latvijoje

email: Janis.Naciscionis@turiba.lv

Algimantas Urmonas -socialinių mokslų daktaras, Viešosios teisès instituto profesorius, Mykolo Romerio Universitete, Lietuvoje.

email: aurmonas@mruni.eu

Jānis Načisčionis - Prof. Dr, the Dean of the Law faculty of Turiba University, Latvia email: Janis.Naciscionis@turiba.lv

Algimantas Urmonas - Doctor of Social Sciences, Professor of Public Law Institute, Mykolas Romeris Faculty of Law, Mykolas Romeris University, Lithuania.

email: aurmonas@mruni.eu

This article is an Open Access article distributed under the terms and conditions of the Creative Commons Attribution 4.0 (CC BY 4.0) License (http://creativecommons.org/licenses/by/4.0/ ). 